\title{
Time Discounting dan Time Preference: Suatu Tinjauan Kritis
}

\author{
Bayu Kharisma \\ Departemen Ilmu Ekonomi, Fakultas Ekonomi dan Bisnis, Universitas Padjadjaran \\ bayu.kharisma@unpad.ac.id
}

\begin{abstract}
Abstrak
Tujuan dari penelitian ini adalah menyoroti secara kritis keterbatasan normatif dan deskriptif mengenai validitas yang terdapat dalam asumsi-asumsi model discounted utility (DU) dan membahas penelitian empiris tentang pilihan antarwaktu (intertemporal choices) yang menyajikan pandangan model teoritis alternatif yang lebih menekankan unsur psikologis dalam pengambilan keputusan pilihan antarwaktu yang sebelumnya gagasan tersebut sempat tidak efektif selama keberadaan model discounted utility (DU). Metode yang digunakan dalam penelitian ini ditujukan untuk mengukur time discounting dan discount rates. Metode pengukuran time discounting menggunakan berbagai studi literatur yang membahas tentang studi lapangan (field studies) dan eksperimental (experimental studies). Hasil penelitian menunjukkan bahwa selain membahas dari sisi ekonomi, penelitian discounted utility (DU) dan pilihan antarwaktu (intertemporal choices) perlu membahas dari pertimbangan psikologis yang lebih mendalam, khususnya mengenai neuroeconomics. Hal tersebut dikarenakan, bahwa masalah mengenai pilihan antarwaktu (intertemporal choice) dihasilkan oleh multiple systems yang bertentangan dengan prioritas-prioritas masih menjadi perdebatan dalam neuroeconomics.
\end{abstract}

Kata Kunci : discounted utility (DU), intertemporal choices, psikologis, neuroeconomics.

\begin{abstract}
The purpose of this study is to critically highlight normative and descriptive limitations regarding the validity of discounted utility (DU) model assumptions and discuss empirical research on intertemporal choices that present the views of alternative theoretical models that emphasize psychological elements in taking inter-time choice decisions that had previously been ineffective during the existence of the discounted utility (DU) model. The method used in this study is intended to measure time discounting and discount rates. The method of measuring time discounting uses a variety of literature studies that discuss field studies and experimental studies. The results of the study show that in addition to discussing from an economic perspective, discounted utility (DU) and intertemporal choices need to be discussed from deeper psychological considerations, especially regarding neuroeconomics. That is because, that the problem of intertemporal choice produced by multiple systems that contradicts priorities is still a debate in neuroeconomics.
\end{abstract}

Keyword : discounted utility (DU), intertemporal choices, psychological, neuroeconomics. 


\section{Pendahuluan}

Pilihan antarwaktu (Intertemporal choices) adalah keputusan yang melibatkan pertimbangan antara biaya dan manfaat pada periode waktu yang berbeda. Perhatian mengenai pilihan antarwaktu sudah dimulai sejak Adam Smith yang menekankan pentingnya pilihan antarwaktu bagi kekayaan negara, John Rae menitikberatkan faktor psikologis dan sosiologis (the effective desire of accumulation) yang berbeda antar negara dan Eugen von Böhm-Bawerk memaparkan pentingnya faktor psikologis dalam preferensi waktu yang kemudian diformalkan oleh Irving Fisher.

Pada tahun 1937, Paul A. Samuelson memperkenalkan model discounted utility (DU), yaitu model yang dapat diaplikasikan pada beberapa periode waktu dengan memberikan penekanan bahwa untuk merepresentasikan pilihan antarwaktu membutuhkan pengukuran utilitas yang mendasar. Model DU menempatkan pilihan antarwaktu untuk seorang pembuat keputusan adalah dengan profil konsumsi $\left(c_{t} \ldots, c_{T}\right)$. Pada asumsi completeness, transitivity dan continuity, pilihan tersebut dapat diinterpretasikan melalui suatu fungsi utilitas intertemporal $U^{t}\left(c_{t} \ldots, c_{T}\right)$. Model DU melakukan penyederhanaan lebih lanjut, dengan mengasumsikan bahwa fungsi utilitas intertemporal seseorang dapat dideskripsikan dengan menggunakan bentuk fungsi sebagai berikut:

$$
U^{t}\left(c_{t}, \ldots, c_{T}\right)={ }_{k=0}^{T-t} D(k) u\left(c_{t+k}\right) \text { dimana } D(k)=\frac{1}{1+}^{k}
$$

pada rumusan ini, $u\left(c_{t+k}\right)$ adalah cardinal instantaneous utility function, yaitu well being seseorang pada period $t+k$ dan $D(k)$ diinterpretasikan sebagai fungsi diskonto (discount function), yaitu relative weight pada periode $t$, ke kondisi well being seseorang pada period $t+k . \rho$ merepresentasikan preferensi waktu seseorang (discount rate) yang dimaksudkan untuk mencerminkan pengaruh kolektif dari motif-motif "psikologis".

Salah satu asumsi sentral dari model discounted utility (DU) adalah bahwa semua motif berbeda yang melandasi pilihan intertemporal bisa dikondensasikan ke dalam sebuah parameter tunggal yang lebih dikenal dengan tingkat diskonto (discount rate). Beberapa asumsi lainnya yang melandasi model discounted utility (DU) adalah sebagai berikut :

a. Integration of New Alternatives with Existing Plans : pada asumsi model DU menunjukkan bahwa seseorang mengevaluasi alternatif baru dengan mengintegrasikan alternatif baru tersebut dengan rencana yang sudah ada.

b. Utility Independence : diasumsikan bahwa nilai keseluruhan dari suatu rangkaian hasil adalah setara dengan jumlah utilitas pada tiap periode dan ditentukan oleh proses discounting dengan menganggap preferensi waktu positif.

c. Consumption Independence : dalam hal ini diasumsikan bahwa secara eksplisit individu well being pada periode $t+k$ dan independen dari konsumsinya pada periode lain, dimana tingkat marjinal substitusi (MRS) antara konsumsi pada periode $\tau$ dan $\tau$ ' independen dengan konsumsi pada periode $\tau$ '”.

d. Stationary Instantaneous Utility : pada saat model DU diterapkan pada masalah spesifik, diasumsikan bahwa cardinal instantaneous utility function $u\left(c_{\tau}\right)$ konstan sepanjang waktu, sehingga keadaan yang dihasilkan dari tiap aktifitas sama pada periode yang berbeda.

e. Independence of Discounting from Consumption : mengasumsikan bahwa fungsi diskonto (discount function) tidak berubah untuk semua bentuk konsumsi. 
f. Constant Discounting and Time Consistency : diasumsikan bahwa diskonto yang konstan (constant discounting) memungkinkan time preference seseorang diringkas menjadi sebuah tingkat diskonto tunggal.

g. Diminishing Marginal Utility and Positive Time Preference : adanya asumsi diminishing marginal utility (dimana $u\left(c_{t}\right)$ berbentuk concave) dan time preference bernilai positif (dimana discount rate $\rho$ positif.).

Samuelson yang pertama kali memperkenalkan model discounted utility (DU) dan Koopmans yang memberikan turunan aksiomatis menyadari adanya keterbatasan normatif dan deskriptif validitas secara empiris asumsi-asumsi yang mendasari model tersebut. Sebagian besar asumsi yang melandasi model DU telah diuji dan diperoleh hasil tidak valid secara empiris. Lebih jauh lagi, anomali-anomali tersebut bukanlah anomali dalam artian dianggap sebagai suatu kesalahan oleh orang yang melakukannya, anomali tersebut tidak dengan serta merta melanggar standar atau nilai dasar yang dipercaya sebagai nilai yang seharusnya dijadikan pedoman. Anomali-Anomali dalam model DU antara lain : pertama, tingkat diskonto yang diamati secara empiris tidak konstan sepanjang waktu, tetapi menurun mengikuti suatu pola yang sering diacu sebagai hyperbolic discounting, dimana seseorang memiliki suatu tingkat preferensi waktu yang menurun. Kedua, tingkat diskonto bervariasi antara tipe-tipe pilihan antarwaktu yang berbeda.

Pemahaman seputar pilihan antarwaktu yang diperoleh dari penelitian empiris memunculkan beberapa model teoritis alternatif. Beberapa model mencoba untuk mendapatkan realisme deskriptif yang lebih baik dengan memodifikasi tingkat diskonto, misalnya tingkat diskonto yang menurun atau "model of hiperbolic discounting ". Selain itu, memasukkan argumentasi tambahan fungsi utilitas seperti utility of anticipation dan yang lebih radikal yaitu memasukkan misprediksi sistematis dari utilitas masa depan (systematic mispredictions of future utility).

Tujuan dari penelitian ini adalah menyoroti secara kritis keterbatasan normatif dan deskriptif mengenai validitas yang terdapat dalam asumsi-asumsi model discounted utility (DU) dan membahas penelitian empiris tentang pilihan antarwaktu (intertemporal choices) yang menyajikan pandangan model teoritis alternatif yang lebih menekankan unsur psikologis dalam pengambilan keputusan pilihan antarwaktu yang sebelumnya gagasan tersebut sempat tidak efektif selama keberadaan model discounted utility (DU). Outcome measures dalam penelitian ini adalah membuktikan pentingnya berbagai motif yang berbeda, termasuk unsur psikologis dalam memahami pilihan antarwaktu yang tidak bisa disederhanakan ke dalam sebuah parameter tunggal yang dikenal dengan tingkat diskonto (discount rate) seperti yang diasumsikan dalam model discounted utility (DU).

\section{Metodologi Penelitian}

Metode yang digunakan dalam penelitian ini ditujukan untuk mengukur time discounting dan discount rates. Metode pengukuran time discounting menggunakan berbagai studi literatur yang membahas tentang studi lapangan (field studies) dan eksperimental (experimental studies). Pengukuran terhadap time discounting didasarkan pada pengamatan perilaku 'dunia nyata'. Perkiraan lain merupakan derivasi dari prosedur eksperimen (contohnya, jawaban responden atas pertanyaan "Mana yang anda pilih: 100 dollar hari ini atau 150 dollar satu tahun lagi?"). Selain itu, memetakan faktor diskonto perkiraan untuk tiap studi terhadap waktu penerbitan studi itu, dimana faktor diskonnya adalah $\delta=1 /(1+\rho)$. 
Sementara itu, prosedur yang digunakan dalam mengukur discount rates sama dengan perhitungan time discounting, yaitu menggunakan studi lapangan (field studies), dimana tingkat diskonto diperoleh dari keputusan ekonomi yang dibuat seseorang dalam kehidupan seseorang dan studi eksperimental (experimental studies), dimana seseorang mengevaluasi prospek pilihan antarwaktu dengan melibatkan hasil yang riil ataupun hasil hipotetik.

Pada studi eksperimental ada empat prosedur yang digunakan, yaitu tugas pilihan, tugas mencocokkan, tugas harga dan tugas rating. Pada tugas pilihan, subjek diminta untuk memilih antara sebuah imbalan segera yang lebih kecil dan sebuah imbalan tertunda yang lebih besar. Untuk mengidentifikasi tingkat diskonto secara lebih tepat, peneliti sering menghadapkan subjek dengan suatu rangkaian pilihan yang bervariasi penundaannya atau jumlah imbalannya. Beberapa penelitian menggunakan imbalan riil, diantaranya uang, beras, dan jagung. Penelitian lainnya menggunakan imbalan hipotetik, seperti gains dan loss di sisi keuangan. Dalam tugas mencocokkan, responden 'mengisi titik titik' untuk menyetarakan dua opsi intertemporal (sebagai contoh, 100 dollar sekarang $=$.....dollar dalam satu tahun). Dalam tugas rating, tiap responden mengevaluasi suatu hasil yang terjadi pada suatu titik waktu tertentu dengan memberi rating kemenarikannya atau ketidakmenarikannya. Pada tugas penetapan harga, tiap responden menyebutkan keinginan untuk membayar untuk mendapatkan atau menghindari beberapa hasil riil atau hipotetik yang terjadi pada suatu titik waktu tertentu, seperti imbalan uang, kupon makan malam dan penambahan usia seseorang.

\section{Hasil Penelitian}

Model discounted utility (DU) yang terus digunakan secara luas memiliki beberapa kelemahan secara empiris. Bahkan Samuelson yang pertama kali mengemukakan model tersebut dan Tjalling $\mathrm{C}$ Koopmans yang memberikan turunan aksiomatis mengkhawatirkan realisme dari model ini tidak pernah secara empiris terbukti valid sebagai model yang tepat untuk pilihan antarwaktu. Dari berbagai asumsi dalam model tersebut, ada beberapa motif yang menyangkut aspek psikologis perlu ditekankan kembali (untuk menyoroti asumsi-asumsi Model DU dan kritik mengenai validitas model tersebut dapat lihat pada lampiran 1).

Anomali pertama dalam model discounted utility (DU) adalah hyperbolic discounting. Istilah hyperbolic discounting menyatakan bahwa seseorang memiliki suatu tingkat preferensi waktu menurun (dalam hal ini, $\rho_{n}$ adalah penurunan pada $n$ ). Beberapa hal umumnya diinterpretasikan sebagai bukti proses diskonto hiperbola. Pertama, ketika subjek diminta membandingkan suatu imbalan yang lebih kecil dengan segera tapi lebih memilih imbalan yang lebih besar namun dalam jangka waktu lebih lama, tingkat diskonto secara implisit pada horison waktu yang lebih panjang lebih rendah dibandingkan tingkat diskonto pada horison waktu yang lebih pendek. Kedua, suatu bentuk fungsi hiperbola yang mencantumkan tingkat diskonto menurun, lebih baik daripada bentuk fungsi eksponen yang mencantumkan tingkat diskonto konstan. Ketiga, para peneliti telah menunjukkan bahwa preferensi antara dua imbalan yang tertunda bisa berbalik memihak imbalan yang lebih dekat sejalan dengan waktu pada kedua imbalan yang semakin berkurang. Keempat, adanya pola tingkat diskonto menurun terbukti secara empiris. Anomali lainnya dalam model DU antara lain adalah the "sign effect", the "magnitude effect", the "delay-speedup" asymmetry, preference for improving 
sequences dan violations of independence and preference for spread. (penjelasan secara rinci dapat dilihat pada lampiran 2)

Dalam merespon anomali-anomali tersebut, maka model teori alternatif mulai dikembangkan, terutama pada implikasi dari tingkat diskonto menurun yaitu models of hyperbolic discounting. Bentuk fungsi ini pertama kali digunakan untuk meneliti altruism dan pembuatan keputusan individu. Fungsi ini mengasumsikan bahwa tingkat diskonto per periode antara sekarang dan periode berikutnya adalah $(1-\beta \delta) / \beta \delta$, sedangkan tingkat diskonto per periode antara dua periode di masa depan adalah $(1-\delta) / \delta<(1-\beta \delta) / \beta \delta$. Selanjutnya, formulasi ini $(\beta \delta)$ mengasumsikan suatu tingkat diskonto menurun antara periode ini dan berikutnya, tetapi periode selanjutnya tingkat diskonto konstan. Model alternatif lainnya yang telah dikembangkan yaitu adanya argumen tambahan, seperti utilitas antisipasi sampai instantaneous utility function, antara lain adalah habit-formation models, reference-point models, models incorporating utility from anticipation dan visceral influences (penjelasan model-model tersebut dapat dilihat dalam lampiran 3). Model alternatif lainnya yaitu memasukkan misprediksi sistematis dari utilitas masa depan (systematic mispredictions of future utility), dengan beberapa model yang telah dikembangkan yaitu : projection bias, mental-accounting models, choice bracketing, multiple-self models dan temptation utility (penjelasan masing-masing model dapat dilihat pada lampiran 4).

Metode-metode yang digunakan dalam penelitian ini ditujukan untuk mengukur time discounting dan discount rates dengan menggunakan studi lapangan (field studies) dan studi eksperimental (experimental studies). Dalam pengukuran time discounting mengungkapkan tiga pengamatan yang perlu diperhatikan. Pertama, terdapat keberagaman yang luas pada perkiraan (terkait kisaran tingkat diskonto tahunan implisit dari - 6 persen sampai tak terhingga). Kedua, tidak terdapat bukti kemajuan secara metodologis; kisaran perhitungan tidak menciut sejalan dengan waktu. Ketiga, diskonto tinggi mendominasi, dimana sebagian besar poin data cukup jauh dibawah 1, yang merepresentasikan kesetaraan bobot antara masa kini dan masa depan.

Metode dalam mengukur discount rates sama dengan perhitungan time discounting, yaitu menggunakan : Studi lapangan (field studies), dimana tingkat diskonto diperoleh dari keputusan ekonomi yang dibuat seseorang dalam kehidupan seseorang. Dalam studi lapangan, beberapa peneliti memperoleh perkiraan tingkat diskonto dengan mengidentifikasi perilaku dunia nyata yang melibatkan pertukaran antara near future dan distant future.

Penelitian-penelitian awal tipe ini menganalisa pilihan konsumen tentang model alat elektrik yang berbeda, dimana pembeli dihadapkan dengan suatu trade off antara harga pembelian segera dan biaya jangka panjang penggunaan alat tersebut. Pada penelitian ini, tingkat diskonto melampaui suku bunga pasar dan berbeda secara substansial dengan produk kategori lain. Tingkat diskonto untuk pendingin ruangan adalah $17 \%$ hingga $20 \%$; $102 \%$ untuk pemanas air gas, $138 \%$ untuk freezer dan $243 \%$ untuk pemanas air elektrik ; dan $45 \%$ hingga $300 \%$ untuk kulkas.

Sementara itu, dalam studi eksperimental, subjek diminta untuk menyatakan jumlah imbalan segera yang akan membuat individu indiferen terhadap beberapa jumlah penundaan tetap (jumlah penundaan tetapnya adalah 14,75 dollar, 17,25 dollar, 21 dollar, 24,5 dollar, 28,5 dollar; penundaannya adalah 3 hari, 7 hari, 13 hari, 17 hari, 23 hari, dan 29 hari). Satu grup subjek menjawab seluruh 30 permutasi dan mendapatkan imbalan riil, sementara grup subjek lainnya menjawab seluruh 30 permutasi untuk imbalan hipotetik. Coller and Williams (1999) meminta subjek untuk memilih antara 500 dollar dibayarkan 
dalam 1 bulan dan 500 dollar $+\mathrm{x}$ dollar dibayarkan dalam 3 bulan, dimana $\mathrm{x}$ dollar bervariasi antara 1,67 dollar hingga 90,94 dollar lintas 15 pilihan berbeda. Dalam satu kondisi, semua pilihan hipotetik, pada lima kondisi lainnya, satu orang memilih secara acak untuk mendapatkan nilai hasilnya untuk 1 dari 15 pilihannya. Data mentah menunjukkan bahwa tingkat diskonto untuk kondisi hipotetik lebih rendah dibandingkan dengan tingkat diskonto riil.

Ada beberapa hal penting yang dapat disampaikan dalam penelitian "Time Discounting and Time Preference: A Critical Review "oleh Shane Frederick, George Loewenstein, and Ted O'donoghue (2002).

1. Model discounted utility (DU) yang pertama kali diperkenalkan oleh Paul A. Samuelson dan Tjalling C Koopmans yang memberikan turunan aksiomatisnya memiliki beberapa kelemahan dan keterbatasan dalam menangkap motif-motif yang berbeda pada perilaku seseorang. Oleh karena itu, sudah tidak relevan lagi digunakan dalam mencerminkan dunia nyata (real world).

2. Pada penelitian tersebut, upaya untuk menyoroti secara kritis keterbatasan normatif dan deskriptif mengenai validitas yang terdapat pada asumsi-asumsi model discounted utility (DU) serta pembahasan beberapa penelitian empiris tentang pilihan antarwaktu (intertemporal choices) sampai kepada memunculkan beberapa model teoritis alternatif tidak memasukkan unsur resiko dari seseorang dalam mengambil keputusan, antara lain : orang yang menghindari resiko (risk averse), tidak mempertimbangkan resiko (risk neutral) dan menyukai resiko (risk loving) dalam menyoroti unsur psikoligis yang merefleksikan berbagai perbedaan motif seseorang dalam pengambilan keputusan pilihan antarwaktu (intertemporal choices). Dengan demikian, apabila seseorang yang mempunyai sifat risk averse mungkin akan berbeda dengan seseorang yang memiliki sifat risk neutral dan risk loving dalam pengambilan keputusan, dan hasil yang akan didapatkan dari masing-masing sifat resiko individu tersebut akan berbeda.

3. Dalam penelitian itu tidak dibahas mengenai neuroeconomics yang menjelaskan perilaku seseorang melalui interaksi sistem ganda (interaction of multiple systems) dalam pengukuran time discounting yang dihasilkan dari sistem dua saraf manusia. Limbic dan paralimbic cortical structures adalah pilihan yang melibatkan imbalan yang tersedia dengan segera. Dalam hal ini, pentingnya peranan the limbic system (yang mengacu pada daerah orbital dan medial dari frontal cortex, the amygdala, the insular cortex dan subcortical counterparts) pada pilihan antarwaktu yang dianggap penting dalam penentuan emosi seseorang. Beberapa fakta menunjukan bahwa limbic and struktur paralimbic cortical yang dikenal sebagai dopaminergic innervation, diyakini secara preferensi lebih merespon pada imbalan (reward) yang tersedia dengan segera, sedangkan daerah fronto-parietal yang merupakan penentu fungsi kognitif yang tinggi, menentukan semua pilihan antarwaktu (intertemporal choices) (McClure et al. 2004b, 2007), namun pada beberapa penelitian baru-baru ini, bahwa struktur ini merespon pada imbalan yang tertunda.

4. Berkaitan dengan prosedur mengenai pengukuran time discounting melalui studi lapangan dan eskperimen. Dalam prosedur tersebut menghasilkan perbedaan, rumit dan keragaman yang luas dari hasil time discounting yang memungkinkan adanya ketidakstabilan dan inkosistensi dalam penetapan time discounting yang tepat. Selain itu, adanya inflasi, perhitungan adanya kemungkinan bahwa seseorang akan merubah konsumsinya sejalan dengan waktu yang sedang berjalan, ketidaksempurnaan pasar dan ketidakpastian seringkali menjadi faktor ketidakjelasan dan kebingungan dalam 
penetapan time discounting serta adanya inskonsistensi dalam perilaku individu dalam mengambil keputusan.

5. Berkaitan dengan subjek penelitian, dalam penelitian tersebut tidak membahas masalah adanya kemungkinan hewan dijadikan subjek penelitian dalam menentukan besaran discount rates. Pada penelitian Stevens JR, Hallinan EV, Hauser MD tahun 2005 yang berjudul "The ecology and evolution of patience in two new world monkeys", menunjukkan bahwa hewan monyet jenis cotton-top tamarin tidak dapat menunggu lebih dari 8 (delapan) detik untuk tiga kali lipat suatu hadian makanan yang tersedia dengan segera. Hal ini memiliki implikasi dalam menentukan besarnya tingkat diskonto karena adanya perilaku ketidaksabaran (impatient) monyet jenis cotton-top tamarin dalam pengambilan keputusan.

6. Pada penelitian tersebut, masalah prosedur pengukuran tingkat diskonto tidak melibatkan subjek penelitian yang menyangkut perilaku klinis, seperti perokok, pengguna narkoba, pengkonsumsi alkohol, penjudi dan umur dan kemampuan kognitif seseorang (Chabris, Laibson dan Schuldt, 2006)

- Perokok. Sejumlah investigasi telah meneliti adanya hubungan antara perokok dengan discounting, dimana bersama-sama terbukti kuat bahwa perokok terkait dengan tingkat diskonto yang tinggi.

- Konsumsi alkohol yang berlebihan. Berdasarkan hasil penelitian menunjukan bahwa permasalahan dengan minuman alkohol berhubungan dengan tingkat diskonto yang lebih tinggi. Peminum berat memiliki tingkat diskonto dibandingkan kontrol, tingkat diskonto alkoholik aktif relatif lebih tinggi dari alkoholik pecandu yang berhenti, yang pada gilirannya memiliki tingkat diskonto yang lebih tinggi dari kontrol (Petry, 2001a), dan alkohol detoxified memiliki tingkat diskonto yang lebih tinggi dari kontrol.

- Penggunaan obat terlarang. Berdasarkan studi menunjukan hubungan positif antara tingkat diskonto dan penggunaan narkoba untuk obat-obatan terlarang terutama kokain, heroin dan anfetamin.

- Penjudi. Penyakit judi memiliki tingkat diskonto yang lebih tinggi daripada kontrol, baik dalam studi eksperimental (Petry, 2001b) maupun studi di lapangan, dan diantara populasi penjudi dan bukan pelaku judi. Selain itu, adanya hubungan positif antara ukuran keparahan judi dan tingkat diskonto. Petry (2001b) menemukan bahwa frekuensi judi selama 3 (tiga) bulan sebelumnya berkorelasi positif dengan tingkat diskonto.

- Umur. Kesabaran seseorang berbeda pada tingkatan umur. Umur muda menunjukkan kurang sabar daripada umur setengah baya dan orang dewasa yang lebih tua. Read \& Read (2004) melaporkan bahwa orang dewasa yang lebih tua (umur rata-rata adalah 75) adalah kelompok umur yang paling sabar pada saat adanya waktu penundaan hanya setahun. Namun, penelitian ini juga menemukan bahwa orang dewasa yang lebih tua adalah kelompok yang setidaknya kurang sabar apabila terjadi penundaan 3-10 tahun. Hal ini dikarenakan bahwa umur 75 tahun menghadapi resiko kematian. - Kemampuan kognitif. Benjamin, Brown dan Shapiro (2006) dalam (Chabris, Laibson dan Schuldt, 2006) menemukan adanya hubungan negatif antara tingkat diskonto individu dan standar nilai test matmatika untuk murid sekolah menengah atas di Cili dan mahasiswa di Harvard. Silva and Gross (2004) dalam (Chabris, Laibson dan Schuldt, 2006) meneliti bahwa nilai murid tiga terbesar yang mengambil mata kuliah pengantar psikologi mempunyai tingkat diskonto lebih rendah daripada murid dengan nilai menengah dan tiga terbawah. Frederick (2005) memperlihatkan 
bahwa peserta nilai tinggi pada "cognitive reflection" dalam tugas pengambilan keputusan menunjukkan kondisi lebih sabar dalam pilihan antarwaktu. Selanjutnya, Jaroni et al. (2004) memperlihatkan bahwa peserta yang tidak menghadiri perkuliahan mempunyai tingkat diskonto tinggi daripada seseorang yang tidak menghadiri beberapa perkuliahan.

\section{Kesimpulan}

Selain membahas dari sisi ekonomi, disarankan penelitian ini perlu membahas dari pertimbangan psikologis yang lebih mendalam, khususnya mengenai neuroeconomics. Hal tersebut dikarenakan, bahwa masalah mengenai pilihan antarwaktu (intertemporal choice) dihasilkan oleh multiple systems yang bertentangan dengan prioritas-prioritas masih menjadi perdebatan dalam neuroeconomics. Dalam penelitian tersebut masih terbatas dalam ketersediaan informasi menyangkut masalah data, kusioner yang digunakan dalam eksperimen dan studi lapangan. Selain itu, laporan yang menunjukkan hasil secara detail dari studi lapangan dan eksperimen dalam penentuan waktu diskonto (time discounting) dan tingkat diskonto (discount rate). Berkaitan dengan subjek penelitian. Dalam penelitian tersebut diharapkan dapat melibatkan responden manusia dan hewan. Hal ini ditujukan untuk melihat perbandingan besaran tingkat diskonto, karena respon dan perilaku manusia dengan hewan berbeda dalam mengambil keputusan. Masih terbatasnya studi lapangan dan eksperimental dalam penelitian tersebut yang melibatkan dua atau lebih imbalan (reward). Oleh karena itu, dimungkinkan dalam prosedur pengukuran time discounting dan discount rate dengan melibatkan adanya imbalan minimal 2 (dua) atau lebih, termasuk memasukkan faktor inflasi, ketidakpastian dan ketidaksempurnaan pasar.

\section{Daftar Pustaka}

Frederick, S. (2005). Cognitive reflection and decision making. Journal of Economic Perspectives, 19(4), 24-42.

Frederick, S., G. F. Lowenstein, T. O’Donoghue. (2002). Time discounting and time preference: A critical review. J. Economics. Literature 40(2) 351-401.

Jaroni, J.L., Wright, S.M., Lerman, C., \& Epstein, L.H. (2004). Relationship between education and delay discounting in smokers. Addictive Behaviors, 29, 1171-1175.

Laibson, C \& Schuldt. (2006). Intertemporal Choice. The New Palgrave Dictionary of Economics (2nd ed.). London: Palgrave Macmillan.

Loewenstein, Rick, and Cohen. (2008). Neuroeconomics. Annu. Rev. Psychol. 2008. 59:647-72.

Petry, N.M. (2003). Discounting of money, health, and freedom in substance abusers and 
controls. Drug and Alcohol Dependence, 71, 133-141.

Petry, N.M., \& Casarella, T. (1999). Excessive discounting of delayed rewards in substance abusers with gambling problems. Drug and Alcohol Dependence, 56, 2532 .

Samuelson, P. A. (1937). A note on measurement of utility. Rev.Econom. Stud. 4(2) 155161.

Samuelson, Paul. (1952). "Probability, utility, and the independence axiom." Econometrica, 20:4, pp. 670-78

Stevens JR, Hallinan EV, Hauser MD. (2005). The ecology and evolution of patience in two NewWorld monkeys. Biol. Lett. 1:223-26

\section{LAMPIRAN 1}

Integration of New Alternatives With Existing Plans. Suatu asumsi sentral pada sebagian besar model-model pilihan antarwaktu termasuk model DU adalah bahwa seseorang mengevaluasi alternatif baru dengan mengintegrasikan alternatif-alternatif baru tersebut dengan rencana yang sudah ada. Sebagai ilustrasi, misalnya ada seseorang dengan rencana konsumsi yang sudah ada $\left(c_{t}, \ldots, c_{T}\right)$ yang ditawari sebuah pilihan antarwaktu sebut saja prospek X, yang mungkin sesuatu seperti sebuah pilihan untuk membayarkan 5000 dollar sekarang dan ia akan menerima 10.000 dollar dalam lima tahun. Integrasi berarti prospek $X$ tidak dievaluasi secara terpisah, tetapi dengan cara bagaimana ia mengubah agregat konsumsi seseorang pada semua periode masa depan. Maka, untuk mengevaluasi prospek $\mathrm{X}$, orang tersebut harus memilih seperti apa jalur konsumsi barunya $\left(c^{\prime}, \ldots, c^{\prime}\right)$ jika ia nantinya menerima prospek $\mathrm{X}$, dan harus menerima prospek tersebut jika $U^{t}\left(c^{\prime}, \ldots, c^{\prime} T\right)>U^{t}\left(c_{t}, \ldots, c_{T}\right)$. Suatu cara alternatif untuk memahami integrasi adalah dengan mengenali bahwa prospek intertemporal mengubah set anggaran seseorang. Jika jumlah dana awal seseorang adalah $E_{0}$, maka menerima prospek $\mathrm{X}$ akan mengubah dananya menjadi $\mathrm{E}_{0} \cup \mathrm{X}$. Membiarkan $B(E)$ menyatakan set anggaran seseorang tersebut dengan dana $E$ yang artinya set aliran konsumsi yang dimungkinkan dengan adanya dana $E$. Model DU menyatakan bahwa seseorang sebaiknya menerima prospek X jika:

$$
\left(c_{t}, \ldots, c_{T}\right) \stackrel{\operatorname{Max}}{B}\left(E_{0} \quad X\right)^{T}{ }_{t=1}^{T} \frac{1}{1+} \div u(c)>\left(c_{t}, \ldots, c_{T}\right)^{\operatorname{Max}} B\left(E_{0}\right)^{T}{ }_{t=1}^{T} \frac{1}{1+} \div{ }^{t} u(c)
$$

meskipun integrasi secara normatif meyakinkan, tetapi hal ini bisa jadi terlalu sulit untuk dapat benar-benar dilakukan. Seseorang mungkin tidak memiliki rencana yang tersusun baik seputar aliran konsumsi masa depannya, atau tidak mampu (atau tidak mau) untuk 
melakukan penghitungan ulang rencana baru yang lebih optimal setiap kali dia membuat suatu pilihan antarwaktu.

Utility Independence, dimana dalam model DU secara eksplisit menganggap bahwa nilai keseluruhan atau 'utilitas global' dari suatu rangkaian hasil adalah setara dengan jumlah (diskonto) utilitas pada tiap period. Maka, distribusi utilitas lintas waktu tidak membuat perbedaan dan ditentukan oleh proses discounting, dengan menganggap preferensi waktu positif. Namun kenyataanya hal tersebut sulit untuk dilakukan. Sebagai contoh, suatu preferensi yang memilih suatu utilitas profil yang flat daripada utilitas profil naik turun dengan penggunaan utilitas diskonto yang sama. Asumsi independensi utilitas ini implikasinya tidak sesuai dengan kenyataan yang sebenarnya, dimana mengabaikan berbagai bentuk pilihan pola utilitas apapun sepanjang waktu.

Consumption Independence, dimana suatu utilitas hasil tidak dipengaruhi oleh hasil yang dialami pada periode sebelumnya atau yang akan datang. Sebagai contoh, bahwa preferensi seseorang antara sebuah restoran Thailand dan restoran Italia untuk malam ini tidak harus bergantung pada apakah seseorang tersebut makan makanan Italia semalam dan tidak juga terkait apakah seseorang berencana untuk makan makanan Italia besok. Namun, disadari oleh Samuelson dan Koopmans, tidak ada bentuk rasionalisasi apapun yang meyakinkan untuk asumsi ini.

Stationary Instantaneous Utility. Pada saat model DU diterapkan pada problemproblem spesifik, seringkali diasumsikan bahwa cardinal instantaneous utility function (kebutuhan utama dan segera) $u\left(c_{\tau}\right)$ konstan sepanjang waktu, sehingga kondisi yang dihasilkan dari setiap aktivitas sama pada periode yang berbeda. Sebagian besar ahli ekonomi dapat memahami bahwa keadaan stasioner (tidak bergerak) pada instantaneous utility function tidak masuk akal pada banyak situasi, karena preferensi orang-orang kenyataannya berubah-ubah sepanjang waktu dalam cara-cara yang dapat diprediksi maupun yang tidak dapat diprediksi. Meskipun asumsi yang tidak realistis ini sering dipertahankan demi kemudahan analisis, namun hal tersebut semakin tidak dapat dibenarkan seiring dengan para ahli ekonomi mulai mendapatkan pemahaman mengenai bagaimana selera berubah seiring waktu berjalan.

Independence of Discounting From Consumption menyatakan bahwa fungsi diskonto (discount function) tidak berubah untuk semua bentuk konsumsi. Namun, kenyataanya bahwa seseorang dihadapkan pada berbagai bentuk konsumsi yang berbeda. Jika utilitas diskonto orang dari sumber berbeda pada tingkatan yang berbeda, maka wacana sebuah preferensi waktu tidak memiliki arti apapun.

Constant Discounting and Time Consistency. Bentuk fungsi diskonto apapun dapat ditulis dalam bentuk :

$$
\mathrm{D}(\mathrm{k})={ }_{n=0}^{k 1} \frac{1}{1+{ }_{n}^{k}} \div
$$

dimana $\rho_{\mathrm{n}}$ merepresentasikan tingkat diskonto per periode untuk periode $n$ - artinya, tingkat diskonto diterapkan antara periode $n$ dan $n+1$. Maka, dengan asumsi bahwa fungsi diskonto mengambil bentuk :

$$
\mathrm{D}(\mathrm{k})=\frac{1}{1+} \div
$$

model DU menganggap suatu tingkat diskonto per periode yang konstan ( $\rho n=\rho$ untuk semua $n$ ). Diskonto konstan membutuhkan suatu kesetaraan dalam cara seseorang mengevaluasi waktu. Artinya, melakukan penundaan atau melakukan percepatan dua 
hasil lama dengan suatu jumlah umum tidak boleh mengubah preferensi antara hasil, jika pada periode $t$ seseorang memilih X pada $\tau$ ke Y pada $\tau+d$ untuk sebagian $\tau$, maka pada periode $t$ seseorang harus memilih $\mathrm{X}$ pada $\tau$ ke Y pada $\tau+d$ untuk semua $\tau$. Asumsi diskonto konstan memungkinkan pilihan waktu seseorang diringkas menjadi sebuah tingkat diskonto tunggal. Jika proses diskonto konstan tidak valid, maka mengkarakterisasi preferensi waktu seseorang membutuhkan proses spesifikasi seluruh fungsi diskonto. Proses diskonto mengimplikasikan bahwa preferensi intertemporal seseorang bersifat konsisten dengan waktu. Artinya, preferensi yang timbul lebih akhir 'menegaskan' preferensi yang terjadi lebih awal. Namun kenyataannya, preferensi individu seringkali tidak konsisten.

Diminishing Marginal Utility and Positive Time Preference. Meskipun bukan merupakan fitur inti dari model DU, hampir semua analisis pilihan antarwaktu mengasumsikan adanya diminishing marginal utility (dimana $u\left(c_{t}\right)$ berbentuk concave) dan time preference bernilai positif (dimana discount rate $\rho$ positif.). Kedua asumsi ini menciptakan tekanan yang bertentangan pada pilihan antarwaktu: utilitas marjinal menurun memotivasi seseorang untuk menyebarkan konsumsi seiring waktu berjalan, sedangkan preferensi waktu positif memotivasi seseorang untuk mengkonsentrasikan konsumsi pada saat ini. Kenyataannya memang bahwa orang-orang akan menyebarkan konsumsi seiring waktu berjalan, maka asumsi utilitas marjinal menurun (ataupun properti lainnya yang memiliki efek serupa) nampaknya kuat. Sedangkan asumsi preferensi waktu positif, di lain pihak, lebih dipertanyakan. Beberapa peneliti telah berargumen seputar preferensi waktu positif dari sisi logika (Hirshleifer 1970; Koopmans 1960; Koopmans, Diamond, dan Williamson 1964; Olson dan Bailey 1981). Intisari penelitian tersebut adalah bahwa preferensi waktu yang negatif atau zero (nol), dikombinasikan dengan suatu tingkat riil positif pada return on saving, akan memicu penundaan tak terbatas untuk semua konsumsi. Tetapi kesimpulan ini mengasumsikan, secara tidak realistis, bahwa individu memiliki rentang hidup tak terbatas dan fungsi utilitas linear (weakly concave). Meskipun demikian, pada analisis ekonometrik tabungan dan substitusi intertemporal, preferensi waktu positif terkadang diperlakukan sebagai suatu batasan yang menjadi identifikasi, dmana pelanggaran pada hal tersebut akan diinterpretasikan sebagai bukti adanya misspesification (kesalahan spesifikasi).

\section{LAMPIRAN 2}

The "Sign Effect" (gains are discounted more than losses). Banyak penelitian yang telah menyimpulkan bahwa gains didiskon pada tingkat yang lebih tinggi daripada losses. Thaler (1981) misalnya, meminta subjek untuk membayangkan bahwa mereka telah menerima surat tilang yang dapat dilunasi sekarang atau nanti dan menyatakan berapa banyak mereka bersedia bayar jika pelunasannya dapat ditunda (tiga bulan, satu tahun, atau tiga tahun). Tingkat diskonto yang dikaitkan dari jawaban-jawaban ini jauh lebih rendah dibanding tingkat diskonto yang didapatkan dari pertanyaan perbandingan mengenai monetary gain (pendapatan moneter). Pola ini terdapat di setiap literatur. Dalam berbagai penelitian, suatu proporsi substansial dari subjek lebih memilih untuk mengalami kerugian dengan segera dibanding menunda-nundanya (Benzion, Rapoport, dan Yagil 1989; Loewenstein 1987; MacKeigan et al. 1993; Mischel, Grusec, dan Masters 1969; Redelmeier dan Heller 1993; Yates dan Watts 1975). 
The "Magnitude Effect" (small outcomes are discounted more than large ones). Dari sebagian besar penelitian yang memiliki beragam ukuran hasil, diperoleh bahwa hasil yang lebih besar di diskonto pada tingkatan yang lebih rendah dibanding hasil yang lebih kecil (Ainslie dan Haendel 1983; Benzion, Rapoport, dan Yagil 1989; Green, Fristoe, dan Myerson 1994; Green, Fry, dan Myerson 1994; Holcomb dan Nelson 1992; Kirby 1997; Kirby dan Marakovic 1995; Kirby, Petry, dan Bickel 1999; Loewenstein 1987; Raineri dan Rachlin 1993; Shelley 1993; Thaler 1981). Pada penelitian Thaler (1981), misalnya, responden secara rata-rata bersikap indiferen antara \$15 segera dan \$60 dalam setahun, $\$ 250$ segera dan $\$ 350$ dalam setahun, dan $\$ 3000$ segera dan $\$ 4000$ dalam setahun, mengimplikasikan tingkat diskonto sebesar 139\%, 34\%, dan 29\%, secara berurutan.

The "Delay-Speedup" Asymmetry. Loewenstein (1988) menunjukkan bahwa tingkat diskonto yang digunakan dapat secara dramatis dipengaruhi oleh apakah perubahan dalam waktu pengiriman sebagai suatu akselerasi atau suatu penundaan dari beberapa poin referensi temporal. Misalnya, responden yang tidak mengharapkan akan menerima sebuah VCR hingga tahun berikutnya bersedia membayar rata-rata \$54 untuk segera mendapatkannya, tetapi bagi mereka yang mengharapkan dengan segera untuk mendapatkannya bersedia membayar \$126 untuk menunda tagihannya selama setahun. Benzion, Rapoport, dan Yagil (1989) dan Shelley (1993) mengulang temuan Loewenstein untuk losses dan juga gains (responden meminta lebih untuk mempercepat pembayaran dibandingkan jumlah yang bersedia mereka bayar untuk menundanya).

Preference for Improving Sequences. Pada penelitian proses diskonto yang melibatkan pilihan antara dua hasil misalnya $X$ pada $\tau$ versus $Y$ pada $\tau^{\prime}$, dimana proses diskonto positif berlaku. Penelitian memeriksa preferensi dari rangkaian hasil dan memperoleh bahwa orang-orang lebih memilih sekuensi meningkat dibanding sekuensi menurun. Misalnya, Loewenstein dan Sicherman (1991) memperoleh bahwa, untuk suatu pekerjaan yang identik, sebagian besar subjek memilih profil pendapatan yang meningkat dibanding yang menurun atau yang flat. Hsee, Abelson, dan Salovey (1991) menemukan bahwa suatu sekuensi dengan peningkatan upah dinilai sama tingginya dengan suatu sekuensi menurun yang memberikan uang lebih banyak. Varey dan Kahneman (1992) mendapati bahwa subjek jauh lebih memilih aliran penurunan ketidaknyamanan daripada aliran peningkatan ketidaknyaman, bahkan pada saat total jumlah keseluruhan ketidaknyamanan pada interval tersebut sebenarnya identik. Loewenstein dan Prelec (1993) mendapati bahwa responden yang memilih antara rangkaian dua peristiwa atau lebih (misalnya, makan malam atau perjalanan liburan) pada akhir pekan berturut-turut atau bulan berturut-turut pada umumnya memilih menyimpan yang terbaik untuk dinikmati belakangan. Chapman (2000) menghadapkan responden dengan rangkaian sakit kepala yang memiliki jumlah total waktu sakit yang sama dimana pilihan pertama adalah perlahan-lahan rasa sakit berkurang dan pilihan kedua adalah perlahan-lahan rasa sakit bertambah. Rangkaian durasinya adalah satu jam, satu hari, satu bulan, satu tahun, lima tahun, dan dua puluh tahun. Untuk semua rangkaian durasi, mayoritas (82 hingga 92\%) subjek memilih rangkaian rasa nyeri yang perlahan-lahan berkurang seiring waktu.

Violations of Independence and Preference for Spread. Penelitian menunjukkan adanya pelanggaran kuat pada independensi. Loewenstein dan Prelec (1993) melakukan penelitian, bayangkan bahwa selama lima akhir pekan yang akan datang, anda harus memutuskan bagaimana anda akan meluangkan sabtu malam anda. Dari tiap pasang rangkaian makan malam di bawah ini, lingkari satu yang anda lebih suka. "Fancy French" artinya sebuah makan malam di sebuah restoran masakan Prancis yang mewah. "Fancy lobster" artinya sebuah makan malam lobster kelas atas di sebuah restoran bintang empat. 
Sebagaimana telah didiskusikan sebelumnya, independensi konsumsi mengimplikasikan bahwa preferensi antara dua profil konsumsi seharusnya tidak dipengaruhi oleh situasi konsumsi pada periode dimana terjadi konsumsi identik pada dua profil. Maka, siapapun yang lebih memilih profil B daripada profil A (yang sama pada periode kelima "Makan di rumah") seharusnya juga memilih profil D daripada profil C (yang sama pada periode kelima "Fancy lobster"). Meskipun demikian, sebagaimana yang ditunjukkan pada data, banyak responden yang melanggar prediksi ini, dengan memilih "fancy French" pada akhir pekan ketiga, jika itu merupakan satu-satunya jamuan mewah yang tersedia pada profil, tetapi memilih "fancy french" pada akhir pekan pertama bila pada profil tersebut terdapat jamuan mewah lainnya. Hasil ini dapat menjelaskan adanya hasrat sederhana untuk melakukan persebaran konsumsi seiring waktu, dimana pada konteks ini, melanggar asumsi independensi yang terkandung pada model DU. Berikut ini contoh eksperimen yang telah dilakukan oleh Loewenstein dan Prelec (1993) dalam pengambilan keputusan selama lima akhir pekan yang akan datang, dimana harus memutuskan bagaimana mengalokasikan waktu dengan meluangkan hari sabtu malam.

\begin{tabular}{|lllllll|}
\hline Options & $\begin{array}{l}\text { First } \\
\text { weekend }\end{array}$ & $\begin{array}{l}\text { Second } \\
\text { weekend }\end{array}$ & $\begin{array}{l}\text { Third } \\
\text { weekend }\end{array}$ & $\begin{array}{l}\text { Fourth } \\
\text { weekend }\end{array}$ & $\begin{array}{l}\text { Fifth } \\
\text { weekend }\end{array}$ & \\
\hline A & $\begin{array}{l}\text { Fancy } \\
\text { French }\end{array}$ & $\begin{array}{l}\text { Eat at } \\
\text { home }\end{array}$ & $\begin{array}{l}\text { Eat at } \\
\text { home }\end{array}$ & $\begin{array}{l}\text { Eat at } \\
\text { home }\end{array}$ & $\begin{array}{l}\text { Eat at } \\
\text { home }\end{array}$ & [11\%] \\
B & $\begin{array}{l}\text { Eat at } \\
\text { home }\end{array}$ & $\begin{array}{l}\text { Eat at } \\
\text { home }\end{array}$ & $\begin{array}{l}\text { Fancy } \\
\text { French }\end{array}$ & $\begin{array}{l}\text { Eat at } \\
\text { home }\end{array}$ & $\begin{array}{l}\text { Eat at } \\
\text { home }\end{array}$ & [89\%] \\
& First & Second & Third & Fourth & Fifth & \\
Weekend & weekend & weekend & weekend & weekend & \\
\hline C & $\begin{array}{l}\text { Fancy } \\
\text { French }\end{array}$ & $\begin{array}{l}\text { Eat at } \\
\text { home }\end{array}$ & $\begin{array}{l}\text { Eat at } \\
\text { home }\end{array}$ & $\begin{array}{l}\text { Eat at } \\
\text { home }\end{array}$ & $\begin{array}{l}\text { Fancy } \\
\text { lobster }\end{array}$ & {$[49 \%]$} \\
& $\begin{array}{l}\text { Eat at } \\
\text { home }\end{array}$ & $\begin{array}{l}\text { Eat at } \\
\text { home }\end{array}$ & $\begin{array}{l}\text { Fancy } \\
\text { French }\end{array}$ & $\begin{array}{l}\text { Eat at } \\
\text { home }\end{array}$ & $\begin{array}{l}\text { Fancy } \\
\text { lobster }\end{array}$ & [51\%] \\
\hline
\end{tabular}

Sumber : Loewenstein dan Prelec (1993) 


\section{LAMPIRAN 3}

Habit-Formation Models. Ekonomi pertama yang mengajukan pemikiran tersebut adalah James Duesenberry (1952), yaitu bahwa utilitas dari konsumsi sekarang ('selera') dapat dipengaruhi oleh tingkat konsumsi lampau. Pemikiran ini secara lebih formal dikembangkan oleh Pollak (1970) dan Ryder dan Heal (1973). Dalam model pembentukan kebiasaan, periode $\tau$ pada instantaneous utility function mengambil bentuk $u\left(c_{\tau}, c_{\tau-1}, c_{\tau-2}, \ldots\right)$, dimana $\partial^{2} u / \partial c_{\tau} \partial c_{\tau^{\prime}}>0$ untuk $\tau^{\prime}<\tau$. Untuk kesederhanaan, kebanyakan model semacam ini mengasumsikan bahwa semua pengaruh dari konsumsi masa lalu untuk utilitas sekarang masuk melalu suatu variabel pernyataan, dimana menganggap bahwa periode $\tau$ instantaneous utility function mengambil bentuk $u\left(c_{\tau} ; \mathrm{z}_{\tau}\right)$, dimana $\mathrm{Z}_{\tau}$ adalah variabel pernyataan yaitu peningkatan pada konsumsi di masa lalu dan $\partial^{2} / \partial c_{\tau} \partial z_{\tau^{\prime}}>0$. Baik Pollak (1970) maupun Ryder dan Heal (1973) mengasumsikan bahwa $\mathrm{Z}_{\tau}$ adalah jumlah eksponen konsumsi masa lalu, atau

$$
z_{t}=a_{i=1}^{\sim i} c_{i}
$$

walaupun pembentukan kebiasaan sering dikatakan mengarah ke preferensi pada peningkatan profil konsumsi, ia dapat, dalam beberapa situasi tertentu, mengarahkan seseorang untuk memilih profil konsumsi menurun atau bahkan nonmonoton. Arah dari pengaruh ini bergantung pada hal-hal seperti bagaimana seseorang telah mengkonsumsi (sebagaimana direfleksikan pada bentuk kebiasaan awal) dan mungkin yang lebih penting, apakah konsumsi sekarang meningkatkan atau menurunkan utilitas masa depan.

Reference-Point Models yaitu memasukkan pemikiran-pemikiran dari teori prospek. Menurut teori prospek, hasil dievaluasi menggunakan suatu fungsi nilai yang didefinisikan selama departures (bergerak, beranjak) dari suatu titik referensi, periode $\tau$ instantaneous utility function mengambil bentuk $u\left(c_{\tau}, r_{\tau}\right)=v\left(c_{\tau}-\mathrm{r}_{\tau}\right)$. Titik referensi, $\mathrm{r}_{\tau}$, mungkin bergantung pada konsumsi masa lampau, ekspektasi (harapan), perbandingan sosial, status quo, dan hal semacamnya. Fitur kedua dari teori prospek adalah bahwa fungsi nilai menunjukkan loss-aversion - yaitu suatu situasi dimana pergerakan negatif dari tingkat referensi konsumsi menurunkan utilitas dalam jumlah yang lebih besar dibanding pergerakan positif. Fitur ketiga dari teori prospek adalah bahwa fungsi nilai menunjukkan diminishing sensitivity (menurunnya tingkat sensitifitas) untuk gain maupun loss, yang artinya fungsi nilai berbentuk concave (cekung) pada gain dan cembung pada loss.

Models Incorporating Utility from Anticipation, dimana jika seseorang mendapatkan kesenangan tidak hanya dari konsumsi sekarang tetapi juga dari antisipasi konsumsi masa depan, maka utilitas instan sekarang akan bergantung secara positif pada konsumsi masa depan yaitu, periode $\tau$ instantaneous utility function akan mengambil bentuk $u\left(c_{\tau} ; c_{\tau+1}\right.$, $c \tau+2, \ldots)$ dimana $\partial u / \partial c_{\tau^{\prime}}>0$ untuk $\tau^{\prime}>\tau$. Model utilitas antisipasi Loewenstein berlaku pada hasil deterministik. Dalam paper baru-baru ini, Caplin dan Leahy (2001) menunjukkan bahwa banyak emosi antisipatoris, seperti kegugupan dan ketegangan, terdorong oleh ketidakpastian tentang masa depan, dan mereka mengajukan suatu model baru yang memodifikasi teori utilitas yang diharapakan untuk diintegrasikan dengan emosi antisipatoris. Mereka lalu menunjukkan bahwa mengintegrasikan kegugupan pada model aset harga dapat membantu menjelaskan puzzle equity premium dan puzzle tingkat bebas risiko, karena rasa gugup menciptakan selera untuk aset bebas resiko dan 
ketidaksukaan pada aset yang berisiko. Seperti Loewenstein, Caplin dan Leahy menekankan bagaimana utilitas antisipatoris dapat mengarah pada inkonsistensi waktu. Koszegi (2001) juga mendiskusikan sejumlah implikasi utilitas antisipatoris.

Visceral Influences berusaha mengintegrasikan pengaruh "insting” seperti rasa lapar, hasrat seksual, sakit fisik, kegemaran berlebihan pada suatu hal dan yang sebagainya. Loewenstein $(1996,2000$ b) berpendapat bahwa ilmu ekonomi harus lebih menganggap serius implikasi dari fluktuasi transien pada selera. Secara formal, pengaruh insting berarti bahwa instantaneous utility function seseorang mengambil bentuk $c_{t}=c_{t}{ }^{\prime}$ dimana $d_{\tau}$ merepresentasikan vektor keadaan insting pada periode $\tau$. Keadaan insting bersifat endogen (setidaknya hingga tingkatan tertentu), misalnya, rasa lapar seseorang bergantung pada berapa banyak seseorang mengkonsumsi pada periode sebelumnya dan oleh karena itu mengarah pada interdependensi konsumsi.

\section{LAMPIRAN 4}

Projection Bias. Pada banyak model utilitas alternatif, utilitas orang dari konsumsi, seleranya berubah seiring dengan waktu. Agar membuat keputusan intertemporal dengan benar, seseorang harus secara benar memprediksi bagaimana selera seseorang akan berubah. Loewenstein, O'Donoghue, dan Rabin (2000) menunjukan bahwa, meskipun orang mungkin mengantisipasi sikap kualitatif dari perubahan preferensi mereka, mereka cenderung untuk meremehkan perubahan ini, suatu misprediksi sistematis yang disebut bias proyeksi. Bias proyeksi dapat muncul kapanpun pada saat selera berubah seiring waktu, baik itu melalui pembentukan kebiasaan, perubahan titik referensi, atau perubahan pada keadaan insting. Hal itu dapat memiliki implikasi penting tentang perilaku dan kesejahteraan. Misalnya, orang mungkin meremehkan tingkatan dimana konsumsi sekarang membengkak akan meningkatkan level referensi konsumsi mereka, dan oleh karena itu menurunkan kenikmatan mereka akan konsumsi yang lebih sederhana di masa depan. Ketika pilihan antarwaktu dipengaruhi oleh bias proyeksi, perhitungan preferensi waktu dapat terdistorsi.

Mental-Accounting Models yaitu mengemukakan bahwa orang tidak memperlakukan uang sebagai sesuatu yang dapat dipertukarkan, melainkan memberikan tipe keluaran yang berbeda pada 'keadaan mental' yang berbeda. Model semacam ini dapat membangkitkan perilaku intertemporal yang nampak ganjil ketika dipandang dengan perpektif model DU. Thaler (1985), misalnya, menyatakan bahwa sejumlah kecil uang yang diberi kode uang belanja, sedangkan sejumlah besar uang diberi kode sebagai tabungan, dan seseorang tetap akan lebih ingin membelanjakan uang belanja. Aturan semacam ini dapat memprediksi bahwa orang akan dengan mudah mengeluarkan uang untuk pembelian kecil (misalnya, sepasang sepatu baru), tetapi akan lebih berfikir jika akan melakukan pembelian besar (misalnya meja ruang makan).

Choice Bracketing adalah bahwa seseorang membuat paling banyak beberapa pilihan pada waktu kapanpun, dan umumnya mengabaikan hubungan antara pilihan-pilihan saat ini dengan pilihan-pilihan masa depan atau masa lalu lainnya. Apabila pilihan-pilihan ini yang terjadi di waktu yang sama disebut Choice Bracketing.

Multiple-Self Models, dalam model ini memandang pilihan antarwaktu sebagai hasil dari suatu konflik antara beberapa diri (multiple selves). Sebagian besar multiple-self 
models memformulasikan bahwa terdapat diri pikir pendek yang sedang berkonflik dengan diri pikir panjang, dan seringkali menarik analogi antara pilihan antarwaktu dan beragam model berbeda seputar interaksi strategis interpersonal. Beberapa model (sebagai contoh, Ainslie dan Haslam 1992; Schelling 1984; Winston 1980) mengasumsikan bahwa terdapat dua faktor, yang satu pikir pendek dan yang satu pikir panjang, yang secara bergantian mengambil alih kendali perilaku. Secara spesifik, Multiple-Self Models telah digunakan untuk memahami luasnya strategi kendali diri yang orang gunakan untuk mengatur perilaku masa depan mereka sendiri. Lebih jauh lagi, model-model ini memberikan banyak inspirasi bagi model formal terkini tentang sophisticated hyperbolic discounting (mengikuti Laibson, 1994. 1997).

Temptation Utility. Dalam suatu paper terbaru, Gul dan Pesendorfer (2001) memformulasikan bahwa orang memiliki "temptation utility", dimana mereka mengalami disutilitas dari tidak memilih opsi yang paling bagus atau pali baik pada saat ini. Seseorang mungkin akan lebih baik jika opsi tertentu (yang menimbulkan godaan) tidak ada, bahkan jika dia tidak memilih opsi tersebut. Sebagai hasilnya, orang mungkin akan mau membayar di depan untuk mengeliminasi opsi tersebut, atau dengan kata lain, dia mungkin memiliki preferensi komitmen. 